\title{
Kinetics of the oxidation reactions and decomposition of pyrite
}

\section{(Cinética das reações de oxidação e de decomposição da pirita)}

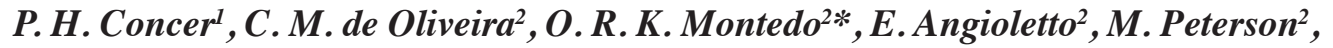 \\ M. A. Fiori ${ }^{3}$, R. de F. P. M. Moreira ${ }^{1}$ \\ ${ }^{1}$ Programa de Pós-Graduação em Engenharia Química, Universidade Federal de Santa Catarina, \\ Florianópolis, SC, Brazil 88040-900 \\ ${ }^{2}$ Programa de Pós-Graduação em Ciência e Engenharia de Materiais, Universidade do Extremo Sul \\ Catarinense, Av. Universitária, 1105, P.O. Box 3167, Criciúma, SC, Brazil 88806-000 \\ ${ }^{3}$ Programa de Pós-Graduação em Tecnologia e Gestão da Inovação, Universidade Comunitária Regional de \\ Chapecó, Chepecó, SC, Brazil 89809-000 \\ paulaconcer@gmail.com,machadodeoliveirac@gmail.com,*oscar.rkm@gmail.com,ean@unesc.net, \\ mpe@unesc.net,marciofiori@gmail.com,regina@enq.ufsc.br
}

\begin{abstract}
Despite the great abundance of pyrite in nature and its role as one of the main sources of $\mathrm{SO}_{2}$ emissions in industrial processes, there is little definitive information about the kinetics and mechanisms of pyrite oxidation and decomposition reactions. This work aimed to determine the viability of applying the Friedman method for kinetic parameter determination to the oxidation and decomposition reactions of pyrite from the coal mining industry in order to obtain pyrite-based magnetic materials. Such method is based on the use of experimental weight loss data obtained using thermogravimetric analysis (TG) for the determination of the reaction activation energies. Thus, the activation energy, the pre-exponential factor and the reaction order were obtained using TG curves with different heating rates $\left(2.5,5.0,7.5\right.$ and $\left.10.0 \mathrm{~K} \cdot \mathrm{min}^{-1}\right)$. For inert atmosphere, the calculated activation energies of approximately $280 \mathrm{~kJ}^{\mathrm{mol}}{ }^{-1}$ agree with the literature values. The reaction in oxidant atmosphere showed two predominant weight loss regions, suggesting the existence of two different reactions. The $482 \mathrm{~kJ} \cdot \mathrm{mol}^{-1}$ value obtained for the activation energy of the second weight loss that occurred at approximately $770 \mathrm{~K}$ was similar to the results reported by other authors. For the observed weight loss at approximately $650 \mathrm{~K}$, similar values were not found in the literature to compare to the results of the Friedman method. The theoretical activation energy was therefore determined with empirical equations. A theoretical value of approximately $1000 \mathrm{~kJ} \cdot \mathrm{mol}^{-1}$ was obtained for the decomposition of pyrrhotite. The values found for the other kinetic parameters showed inconsistencies.
\end{abstract}

Keywords: pyrite, oxidation reactions, decomposition reactions, kinetic parameters.

\section{Resumo}

Apesar da abundância de pirita na natureza e seu papel como uma das principais fontes de emissões de $\mathrm{SO}_{2}$ em processos industriais, há pouca informação sobre a cinética e os mecanismos das reações de oxidação e de decomposição da pirita. Este trabalho teve o objetivo de determinar a viabilidade de aplicação do método de Friedman para a determinação dos parâmetros cinéticos para as reações de oxidação e de decomposição da pirita obtidas das indústrias de extração de carvão de forma a se obter materiais magnéticos baseados na pirita. Este método está baseado no emprego da perda de massa experimental obtida usando-se análise termogravimétrica (TG) para a determinação das energias de ativação das reações. Assim, a energia de ativação, ofator pré-exponencial e a ordem de reação foram obtidos usando-se curvas de TG com diferentes taxas de aquecimento (2,5, 5,0, 7,5 e 10,0 K.min $\left.{ }^{-1}\right)$. Para atmosfera inerte, as energias de ativação calculadas de aproximadamente $280 \mathrm{~kJ} \mathrm{~mol}^{-1}$ estão em acordo com os valores encontrados na literatura. A reação em atmosfera oxidante mostrou duas regiões predominantes de perda de massa, sugerindo a existência de duas reações. O valor obtido

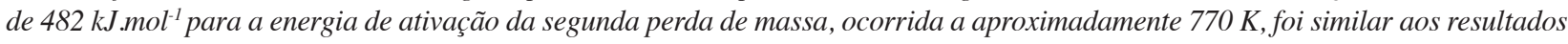
relatados por outros atores. Para a perda de massa observada a aproximadamente $650 \mathrm{~K}$, valores similares não foram encontrados na literatura para se comparar com os valores do método Friedman. A energia de ativação teórica foi, entretanto, determinada com equações empíricas. Um valor teórico de aproximadamente $1000 \mathrm{~kJ} . \mathrm{mol}^{-1}$ foi obtido para a reação de decomposição de pyrrhotita. Os valores encontrados para outros parâmetros cinéticos se mostraram inconsistentes.

Palavras-chave: pirita, reações de oxidação, reações de decomposição, parâmetros cinéticos.

\section{INTRODUCTION}

Pyrite is a mineral with a compact structure [1] that is abundant in nature and is found in high concentration and as an impurity in many types of minerals and coals. For this reason, it is one of the main sources of $\mathrm{SO}_{2}$ emissions in industrial processes [2]. Despite the importance of this material, little definitive information is available about its 
kinetics and reaction mechanisms. From a mechanistic point of view, pyrite decomposition is a complicated process because it involves a high number of mass and heat transfer steps [1]. It is possible to approximate the thermal decomposition of pyrite to form pyrrhotite by the non-reacting nucleus model. When the reaction involves gaseous reagents and/or gaseous products and the diffusion process is slow, the reaction can be controlled by the diffusion step through the stagnant film of gas and product layer. Nevertheless, when the reaction step is slow compared to the diffusion step, the reaction can be controlled by the chemical reaction. When neither of these two steps play a dominant role, the process is controlled by a combination of these steps (mixed control) [2]. Depending on the reactions conditions, pyrite oxidation can occur by different mechanisms. The direct oxidation is controlled by the oxygen diffusion and can be adapted to the non-reacted nucleus model. When the decomposition occurs according to the two-step mechanism, the first step, which is the thermal decomposition of pyrite, follows the proposed model for decomposition at inert atmosphere. Nevertheless, the oxidation of the formed pyrrhotite at the first step is an exothermic process that promotes an increase in the temperature of the material. This phenomenon can affect the pyrite thermal decomposition kinetics, leading to the reaction occurring rapidly in an oxidant atmosphere [3].

The activation energy is an important kinetic parameter that indicates the magnitude of the influence of the temperature on the reaction. Hu et al. [4] used the Friedman isoconversional method for the determination of kinetic parameters in an extremely pure pyrite. The good results obtained for the same basic material (pyrite) encouraged the use of such method for the impure mineral used in this work. Several researchers have confirmed that activation energies for the pyrite decomposition can be divided in two groups based on the controlling step of the process. For high activation energy values of approximately $290 \mathrm{~kJ} . \mathrm{mol}^{-1}$, sulfur dissipation is fast and the process is controlled by decomposition. For low activation energy values of approximately $110 \mathrm{~kJ} \cdot \mathrm{mol}^{-1}$, sulfur dissipation is too slow, and therefore, the evaporation of the sulfur at the pyrite/pyrrhotite interface is the controlling step [5]. The present work aimed to determine the viability of the application of the Friedman isoconversional method for the determination of the kinetic parameters of the oxidation and decomposition reactions of pyrite from the coal mining industry. The activation energy $\left(E_{a}\right)$, the pre-exponential factor $(A)$ and the reaction order $(n)$ were obtained by analysis of the thermogravimetric curves at different heating rates. The obtained results were compared with literature values.

\section{EXPERIMENTAL}

Material: the pyrite used in this study was collected in a coal company situated in the south of Santa Catarina State
(Brazil). Chemical analysis of such material is shown in Table I.

Table I - Chemical analysis of pyrite. [Table I - Análise química da pirita.]

\begin{tabular}{cc}
\hline Element & Content $(\mathrm{wt} \%)$ \\
\hline Iron & 39.80 \\
Sulfur & 39.70 \\
Silicon & 5.20 \\
Aluminum & 2.20 \\
Calcium & 0.54 \\
Potassium & 0.13 \\
Titanium & 0.13 \\
Lead & 0.10 \\
Tungsten & 0.05 \\
Magnesium & 0.04 \\
Manganese & 0.03 \\
Chrome & 0.02 \\
Zinc & 0.02 \\
Nickel & 0.01 \\
Phosphorus & 0.01 \\
Carbon & 5.10 \\
Moisture & 6.92 \\
\hline
\end{tabular}

Thermal analysis: the thermal behavior of the studied pyrite was evaluated in a thermogravimetric analyzer (Shimadzu, TGA-50). The experimental conditions were: i) air atmosphere: heating rates of 2.5, 5.0, 7.5 and $10 \mathrm{~K} \cdot \mathrm{min}^{-1}$, a sample mass of approximately $15 \mathrm{mg}$, and a synthetic air flow of $50 \mathrm{~mL} \cdot \mathrm{min}^{-1}$; ii) nitrogen atmosphere: heating rates of 2.5, 5.0, 7.5 and $10 \mathrm{~K} \cdot \mathrm{min}^{-1}$, a sample mass of approximately $10 \mathrm{mg}$, and a nitrogen flow of $50 \mathrm{~mL} \cdot \mathrm{min}^{-1}$.

Kinetic study of the pyrite decomposition/oxidation reactions: the kinetic parameters were obtained by applying the Friedman isoconversional method [4]. Isoconversional methods are based on the concept that the temperature change resulting from the heating rate is a function of the activation energy of the process. The reaction rate, the Arrhenius rate constant and the heating rate can be defined, respectively, by Equations $\mathrm{A}, \mathrm{B}$ and $\mathrm{C}$ :

$$
\begin{aligned}
& -\frac{d w}{d t}=f(w) \cdot k \\
& k=A \cdot e^{\frac{-E a}{R T}} \\
& \beta=\frac{d T}{d t}
\end{aligned}
$$

where $w$ refers to the remaining sample at a given time period specified by $\left(w_{t}-w_{f}\right)$, where $w_{t}$ and $w_{f}$ are the sample masses at the reaction times $t$ and $t_{f}$ (end of the thermogravimetric analysis), respectively [4]. Substituting Equations B and C 
into Equation A, one can obtain Equation D:

$$
-\frac{\mathrm{dw}}{\mathrm{dt}}=\frac{\mathrm{A}}{\beta} \cdot \mathrm{e}^{\frac{-\mathrm{Ea}}{\mathrm{RT}}} \cdot \mathrm{f}(\mathrm{w})
$$

Assuming that the pyrolysis reaction follows $n$ th-order kinetics, the function $f(x)$ is defined by:

$$
f(x)=(1-x)^{n}
$$

In the case of the Friedman method, the kinetic parameters are obtained using the differential method. Thus, the activation energy can be calculated without the knowledge of the form of $f(x)$. The final form for the Friedman equation is expressed by:

$$
\ln \left[\beta\left(-\frac{d w}{d t}\right)\right]=\ln [A f(w)]-\frac{E_{a}}{R T}
$$

The graphic representation of $\ln [\beta(-\mathrm{d} w / \mathrm{d} t)]$ versus $1 / T$ for different weights results in a straight line with a slope of $\left(-E_{a} / R\right)$. Once the value of $\ln [A . f(w)]$ was defined in the linearization of the Friedman method, the value of $n$ can be obtained from the linearization of Equation G [4]:

$$
\ln [\mathrm{Af}(\mathrm{w})]=\ln \mathrm{A}+\mathrm{n} \ln \mathrm{w}
$$

\section{RESULTS AND DISCUSSION}

Kinetics of the decomposition and oxidation reactions in inert atmosphere

Fig. 1 shows the thermogravimetry curves obtained in inert atmosphere $\left(\mathrm{N}_{2}\right)$ for different heating rates. To obtain the kinetic parameters, curves of $\left(w_{t}-w_{f}\right) v s$. temperature were plotted (Fig. 2). The values of the selected $w_{t}-w_{f}$ varied between 1.54 and $1.72 \mathrm{mg}$ because the most significant weight loss was observed in this region. Fig. 3 shows the linear regressions related to the Friedman method. The determination of the square straight minimum from the

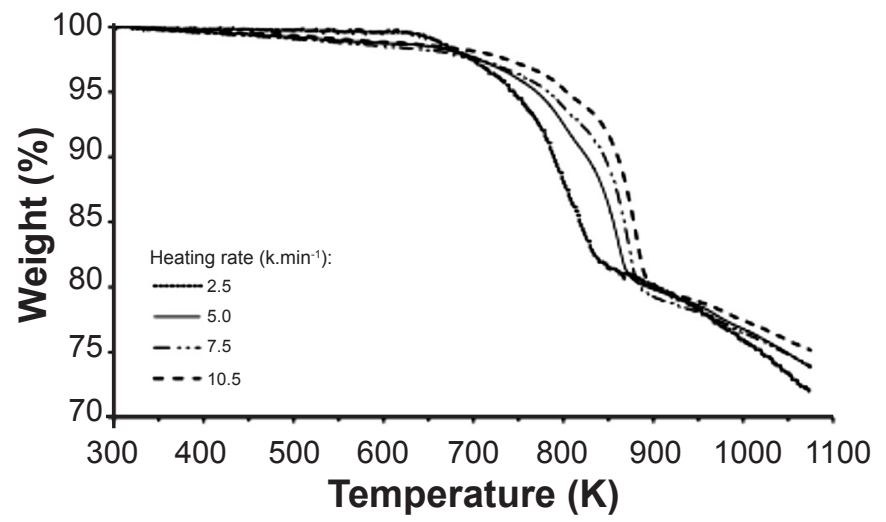

Figure 1: Results of thermogravimetric analysis in inert atmosphere. [Figura 1: Resultados da análise termogravimétrica em atmosfera inerte.]

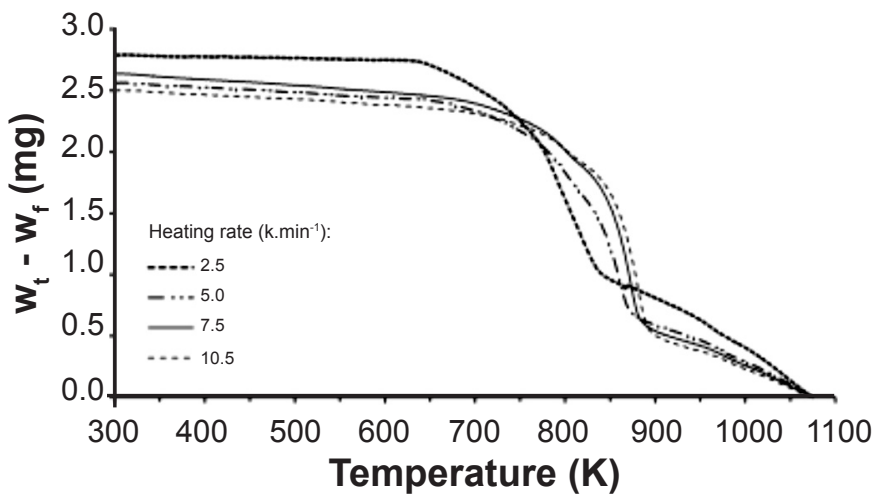

Figure 2: $\left(w_{t}-w_{f}\right)$ versus temperature obtained in inert atmosphere. [Figura 2: $\left(w_{t}-w_{p}\right)$ versus temperatura obtida em atmosfera inerte.]

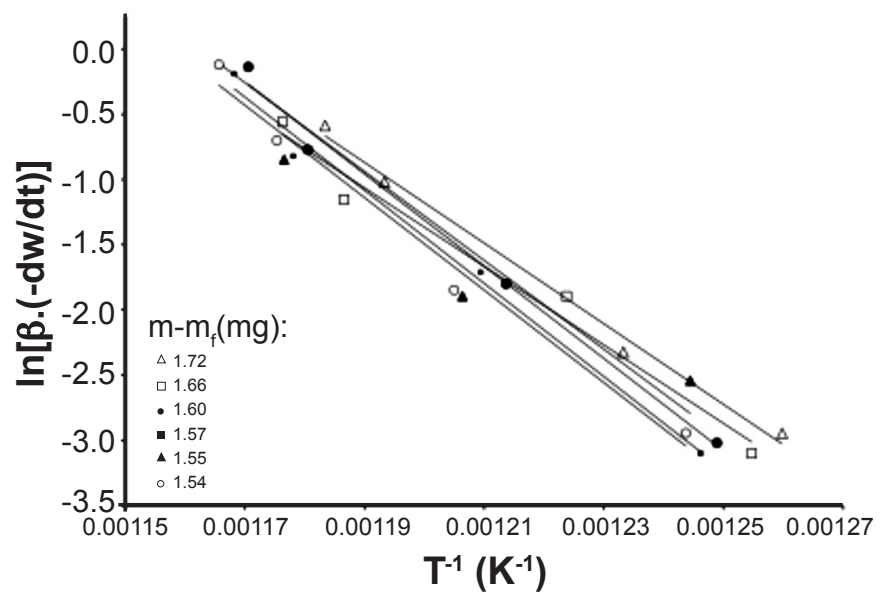

Figure 3: Graph of Friedman method for estimation of global activation energy for pyrite decomposition in inert atmosphere. [Figura 3: Gráfico do método de Friedman para estimativa da energia de ativação global para decomposição da pirita em atmosfera inerte.]

Table II - Activation energies for inert atmosphere. [Tabela II - Energias de ativação para atmosfera inerte.]

\begin{tabular}{cc}
\hline$w_{t}-w_{f}(\mathrm{mg})$ & $E_{a}\left(\mathrm{~kJ}^{\mathrm{mol}}{ }^{-1}\right)$ \\
\hline 1.72 & 256.7 \\
1.66 & 250.1 \\
1.60 & 293.9 \\
1.57 & 296.6 \\
1.55 & 283.1 \\
1.54 & 294.4 \\
Average & 279.2 \\
\hline
\end{tabular}

graph was used to determine the activation energy $\left(E_{a}\right)$ of pyrite decomposition. The results for the selected $w_{t}-w_{f} v$ alues are shown in Table II. The determined activation energy values of the sample were similar to the literature values. Hong and Fegley [5] found that the activation energy for the pyrite decomposition process is $284.7 \mathrm{~kJ} \cdot \mathrm{mol}^{-1}$, while $\mathrm{Hu}$ et al. [4] determined a value of $268.61 \mathrm{~kJ} \cdot \mathrm{mol}^{-1}$. 
Kinetics of the decomposition and oxidation reactions in oxidant atmosphere

To determine the kinetic parameters of the pyrite oxidation reaction, the same method as applied for the decomposition reaction was used. The thermogravimetry curves obtained in oxidant atmospheres and the curves of $\left(w_{t}-w_{f}\right)$ vs. temperature are shown in Figs. 4 and 5, respectively. The reaction in oxidant atmosphere showed two predominant regions of weight loss, suggesting the existence of two different reactions responsible for these losses. Because of this, $w_{t}-w_{f}$ values for both of the possible reactions were selected. Figs. $6 a$ and $6 \mathrm{~b}$ show the straight line regressions related to the Friedman method for oxidant atmosphere for the $w_{t}-w_{f}$ ranges between 4.40 and $5.20 \mathrm{mg}$ and between 0.60 and $2.20 \mathrm{mg}$, respectively. The graphs in Fig. 6 were used to determine the activation energies of the reactions using the linear minimum regression method. The activation energy values obtained for the selected $w_{t}-w_{f}$ values are shown in Table III.

For the sample treated in the oxidant atmosphere, the obtained values for the activation energy of the second weight loss that occurred approximately at $770 \mathrm{~K}$ were

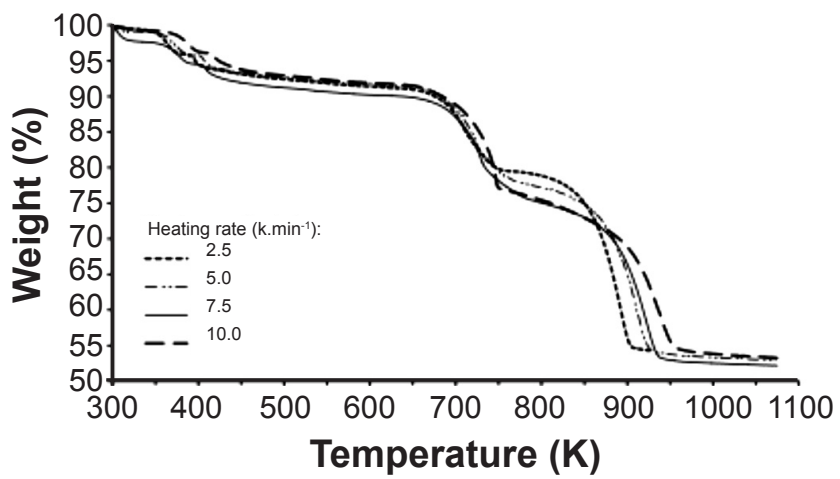

Figure 4: Results of thermogravimetric analysis in oxidant atmosphere.

[Figura 4: Resultados da análise termogravimétrica em atmosfera oxidante.]

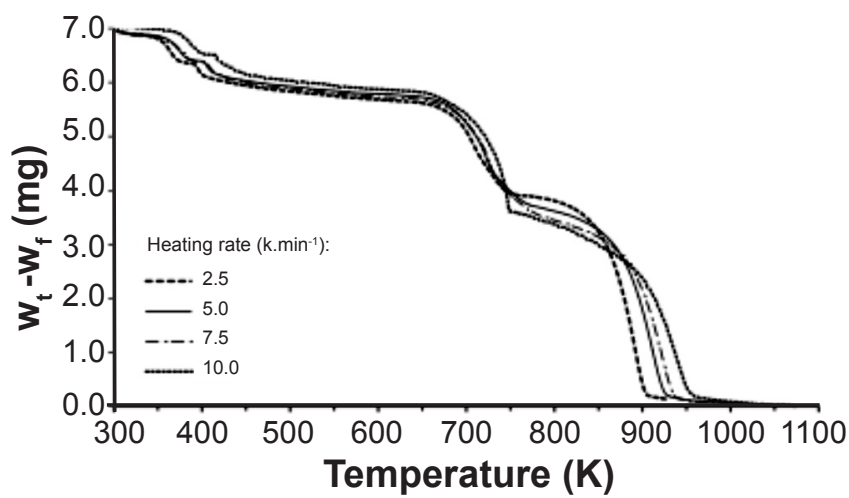

Figure 5: $\left(w_{t}-w_{f}\right)$ versus temperature obtained in oxidant atmosphere.

[Figura 5: $\left(w_{t}-w_{f}\right)$ versus temperatura obtida em atmosfera oxidante.]
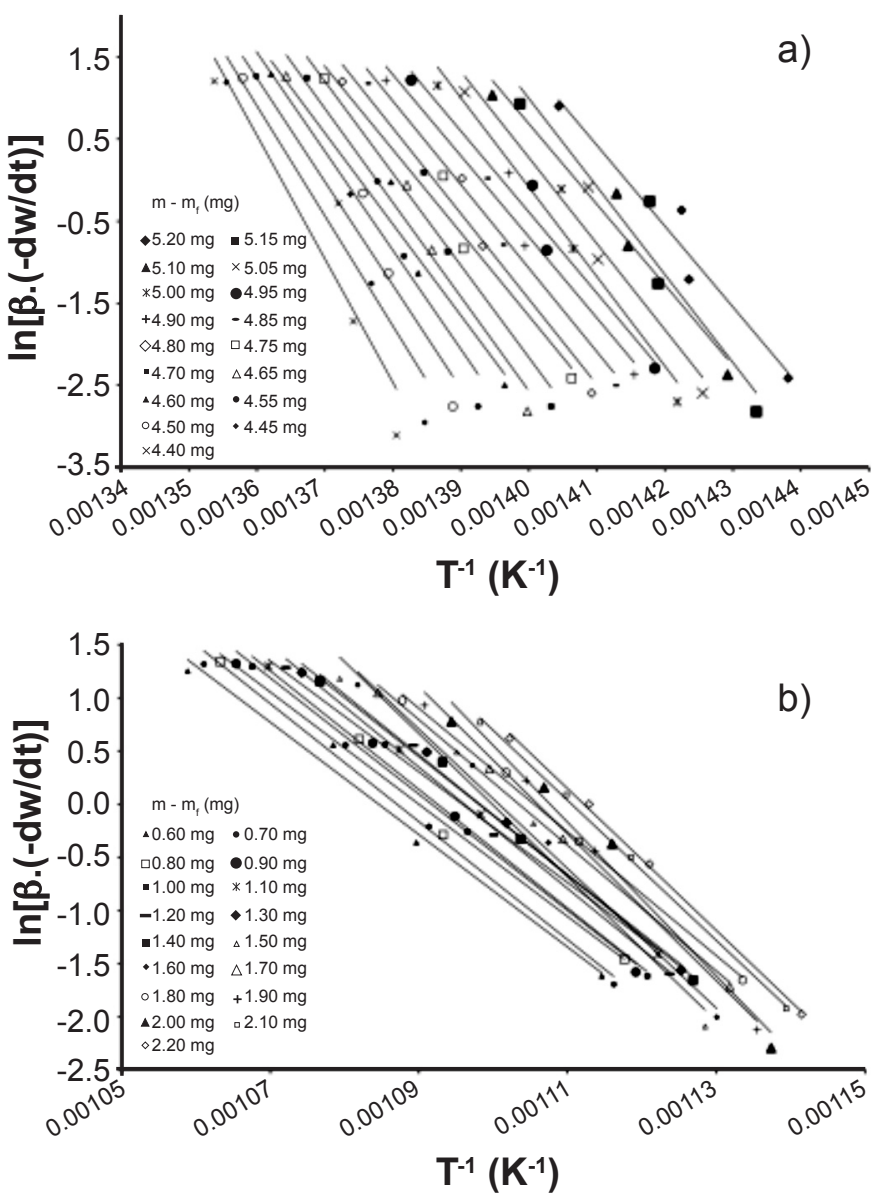

Figure 6: Graphs of Friedman method for the estimation of global activation energy for pyrite decomposition in synthetic air: (a) reaction 1 ; (b) reaction 2.

[Figura 6: Gráficos do método de Friedman para estimativa da energia de ativação global para decomposição da pirita em ar sintético: (a) reação 1; (b) reação 2.$]$

similar to the values in the literature. Živković et al. [6]

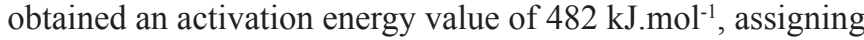
it to reaction:

$$
2 \mathrm{FeSO}_{4} \rightarrow \mathrm{Fe}_{2} \mathrm{O}_{3}+\mathrm{SO}_{2}+\mathrm{SO}_{3}
$$

Similar literature data to the activation energies obtained with the Friedman method for the weight loss observed approximately at $650 \mathrm{~K}$ were not found. Therefore, the theoretical activation energy was determined using empirical equations. We obtained approximately $1000 \mathrm{~kJ} \mathrm{~mol}^{-1}$ as the theoretical value for the decomposition reaction of pyrrhotite, assigning it to reaction:

$$
2 \mathrm{FeS}_{\mathrm{x}}+(1.5+2 \mathrm{x}) \mathrm{O}_{2} \rightarrow \mathrm{Fe}_{2} \mathrm{O}_{3}+2 \mathrm{xSO}_{2}
$$

The values found for the other kinetic parameters (preexponential factor and reaction order) showed inconsistencies. As the studied pyrite was a waste obtained from the coal mining, i.e. pyrite was not a pure material, secondary reactions should occur because of the presence of other elements interfering 
Table III - Activation energies for oxidant atmosphere. [Tabela III - Energias de ativação para atmosfera oxidante.]

\begin{tabular}{cccc}
\hline \multicolumn{2}{c}{$\mathrm{T}=650 \mathrm{~K}$} & \multicolumn{2}{c}{$\mathrm{T}=770 \mathrm{~K}$} \\
$w_{t}-w_{f}(\mathrm{mg})$ & $E a\left({\left.\mathrm{~kJ} \cdot \mathrm{mol}^{-1}\right)}^{2} w_{t}-w_{f}(\mathrm{mg})\right.$ & $E a\left(\mathrm{~kJ} \cdot \mathrm{mol}^{-1}\right)$ \\
\hline 5.20 & 818.9 & 0.60 & 439.5 \\
5.15 & 891.4 & 0.70 & 461.7 \\
5.10 & 815.6 & 0.80 & 438.9 \\
5.05 & 871.3 & 0.90 & 454.6 \\
5.00 & 905.4 & 1.00 & 464.1 \\
4.95 & 820.9 & 1.10 & 433.0 \\
4.90 & 821.6 & 1.20 & 474.0 \\
4.85 & 846.0 & 1.30 & 461.0 \\
4.80 & 865.9 & 1.40 & 471.3 \\
4.75 & 841.6 & 1.50 & 561.4 \\
4.70 & 931.6 & 1.60 & 545.0 \\
4.65 & 953.6 & 1.70 & 491.0 \\
4.60 & 924.5 & 1.80 & 483.2 \\
4.55 & 1001.7 & 1.90 & 574.6 \\
4.50 & 1048.1 & 2.00 & 600.5 \\
4.45 & 1115.1 & 2.10 & 547.3 \\
4.40 & 1250.2 & 2.20 & 553.8 \\
Average & 924.9 & Average & 451.7 \\
\hline
\end{tabular}

in the kinetic parameters. Thus, although the differences in the obtained kinetic parameters in relation to those ones obtained by [4] are reasonable, the Friedman method was not considered an efficient method in this case.

\section{CONCLUSIONS}

The activation energies, obtained using the Friedman method, were found to be similar to values in the literature. For the reaction in an inert atmosphere, the determined activation energy was $279.2 \mathrm{~kJ} \mathrm{~mol}^{-1}$. The reaction in an oxidant atmosphere showed two weight loss events. The first event was associated with pyrite oxidation and showed activation energy of $924.9 \mathrm{~kJ} \cdot \mathrm{mol}^{-1}$. The second event, associated with sulfate decomposition, showed activation energy of $451.7 \mathrm{~kJ} \mathrm{~mol}^{-1}$. The method was inefficient for determination of the other kinetic parameters. The values for the reaction order and pre-exponential factor were inconsistent.

\section{REFERENCES}

[1] N. Boyabat, A.K. Ozer, S. Bayrakçeken, M.S. Gülabog, Fuel Proc. Techn. 85 (2003) 179.

[2] G. Hu, K.D. Johansen, S. Wedel, J.P. Hansen, Progress Energ. Comb. Sci. 32 (2006) 295.

[3] S. Srinivasachar, A.A. Boni, Fuel 68 (1989) 829.

[4] H. Hu, Q. Chen, Z. Yin, P. Zhang, J. Zou, H. Che, Thermochim. Acta 389 (2002) 79.

[5] Y. Hong, B. Fegley, Planetary Space Sci. 46 (1998) 683. [6] Ž. D. Živković, N. Mitevska, V. Savović, Thermochim. Acta 282/283 (1996) 121.

(Rec. 24/02/2016, Rev. 13/04/2016, 13/06/2016, Ac. $13 / 06 / 2016)$ 